\title{
Monosymptomatic Enuresis in Children: Is It Related to Urine pH and Density?
}

\author{
Çocuklarda Monosemptomatik Enürezis: \\ Idrar $\mathrm{pH}$ ve Dansitesi ile IIgili Midir?
}

Özgün Araştırma Research Article

Received/Geliş: 25.12 .2020 Accepted/Kabul: 30.12.2020 Published Online: 29.04.2021

Mehmet Zeynel Keskin Tepecik Eğitim ve Araştırma Hastanesi, Üroloji ABD, Izmir - Türkiye zeynel_akd@hotmail.com ORCID: 0000-0002-9206-5586

i. Aydoğdu 0000-0001-7900-8598 Bezmialem Vakıf Üniversitesi, Çocuk Cerrahisi ABD, istanbul, Türkiye

E. Karaca 0000-0002-9123-4069 U. Miçooğulları 0000-0003-4729-6104 Y.Ö. ìlbey 0000-0002-1483-9160 Tepecik Eğitim ve Araştırma Hastanesi, Üroloji ABD, Izmir, Türkiye

E. Uzun 0000-0001-6593-4902 Istanbul Medeniyet Üniversitesi, Çocuk Cerrahisi ABD, istanbul, Türkiye

Y.E. Aydoğdu 0000-0001-5566-2050 Bezmialem Vakıf Üniversitesi, Tıp Fakültesi, istanbul, Türkiye

H. Metin 0000-0001-9380-4515 Bezmialem Vakıf Üniversitesi, Acil Tıp ABD, istanbul, Türkiye

Cite as: Aydoğdu i, Karaca E, Uzun E, Aydogdu YE, Miçooğulları U, Metin H, et al. Monosymptomatic Enuresis in Children: Is It Related to Urine $\mathrm{pH}$ and Density?. Tepecik Eğit. ve Araşt. Hast. Dergisi. 2021;31(1):76-9.

\author{
Ibrahim Aydoğdu $\odot$, Erkin Karaca $\odot$, Ersan Uzun $\oplus^{\oplus}$, Yaren Ece Aydogdu $\odot$, \\ Uygar Miçooğulları $\odot$, Hüseyin Metin $\odot$, Yusuf Özlem ilbey $\odot$, Mehmet Zeynel Keskin $\odot$
}

\section{ABSTRACT}

Objective: To contribute to the explanation of the etiology of enuresis, which is quite prevalent, by investigating its relationship with urine $\mathrm{pH}$ and density.

Methods: A total of 45558 children were included in the study. Based on screening results, 44201 children without enuresis were assigned to Group 1 and 1357 children with enuresis to Group 2. Complete urinalysis results of all children who had been identified were scanned and values of urine $\mathrm{pH}$ and density were obtained. Intergroup differences with regard to urine $\mathrm{pH}$ and density were analyzed using Student's $t$-test. A $p$ value of $<0.05$ was considered statistically significant.

Results: The group with enuresis was determined to be statistically significantly younger, and has lower urine $\mathrm{pH}$, and density.

Conclusion: The results of our study are consistent with current data. Our study, which will be among one of the largest-scale enuresis studies in the literature, provides guidance to physicians by reminding them the importance of urinary tract infections in the etiology of enuresis.

Keywords: Enuresis, urine $\mathrm{pH}$, urine density

öz

Amaç: Oldukça yaygın olan enürezisin idrar $p H^{\prime} ı$ ve idrar dansitesi ile ilişkisini araştırarak etiyolojisinin açıklanmasına katkıda bulunmak.

Yöntem: Çalışmaya toplam 45558 çocuk dahil edildi. Taramaya göre, enürezisi olmayan 44201 çocuk grup 1'e ve enürezisli 1357 çocuk grup 2'ye alındı. Belirlenen tüm çocukların tam idrar tetkikleri tarandı ve idrar pH ve dansite değerleri elde edildi. İdrar $p H^{\prime} ı$ ve dansitesi açııından gruplar arası farklııklar student $t$-testi kullanılarak analiz edildi. $P<0,05$ değeri istatistiksel olarak anlamlı kabul edildi.

Bulgular: Enürezisli grubun yaş, idrar pH değeri ve idrar dansitesinin daha düşük olduğu istatistiksel anlamlı bulundu.

Sonuç: Çalışmamızın sonuçları güncel verilerle uyumludur. Literatürdeki en büyük enürezis çalışmalarından biri olacak olan çalışmamız, enürezis etiyolojisinde idrar yolu enfeksiyonlarının önemini hatırlatarak hekimlere rehberlik etmektedir.

Anahtar kelimeler: idrar kaçırma, enürezis, idrar pH, idrar dansitesi
(C) Telif hakkı TC. Să̆lkk Bakanlı̆̆ı İzmir Tepecik Eğit. ve Arast. Hastanesi. Logos Tip Yayınclık tarafindan yayınlanmaktadır. Bu dergide yayınlanan bütün makaleler Creative Commons Atff-GayriTicari 4.0 Uluslararası Lisansı ile lisanslanmıştı. (c) Copyright Association of Publication of the T.C. Ministry of Health İmir Tepecik Education and Research Hospital. This journal published by Logos Medical Publishing. Licenced by Creative Commons Attribution-NonCommercial 4.0 International (CC BY) 


\section{INTRODUCTION}

The term "enuresis nocturna" denotes the condition of nighttime urinary incontinence. With regard to its definitions, the International Children's Continence Society (ICCS) has provided the most comprehensive definition. According to the definition by ICCS; enuresis is a condition of bedwetting in children older than five years encountered more than once per month. If bedwetting is observed more than three times per week, it is described as "frequent" (1,2). Meanwhile, American Psychiatric Association (APA) defines enuresis as a condition of nighttime incontinence after the age of 5 at least two times per week for a minimum period of three months ${ }^{(3)}$. The term "monosymptomatic" is used for patients who have no other lower urinary tract symptoms (LUTS) besides enuresis, and while $10 \%$ of school-age children demonstrate enuresis nocturna, and $2-3 \%$ of them enuresis diurna ${ }^{(4,5)}$. The etiology of enuresis has garnered constant attention due to its high prevalence. A wide spectrum of factors including sex, young age, hyperactivity disorder, low economic status, family history, low parental education level, deep sleep pattern, high number of siblings, and having cohabitants in the child's bedroom have been implicated in its etiology ${ }^{(6-11)}$. Many studies have attempted to reveal the etiology of enuresis by focusing on values related to the calcium $\left(\mathrm{Ca}^{+2}\right)$ such as urine calcium levels and bone mineral density. However, none of the studies have directly investigated the relationship of enuresis with parameters of complete urinalysis as urine $\mathrm{pH}$ and density ${ }^{(12-14)}$. This study aims to contribute to the explanation of the etiology of enuresis, which is quite prevalent, by investigating its relationship with urine $\mathrm{pH}$ and density.

\section{MATERIALS and METHODS}

Files of children aged between 4-18 who presented to the urology and pediatric urology polyclinics at Tepecik Education and Research Hospital were scanned retrospectively over the system. During the scan, patients with neurological diseases, history of chronic medication use, traumatic surgery or accidents that could have resulted in urethral obstruction were excluded from the study. A total of 45558 children were included in the study. Based on a scan, 44201 children without enuresis were assigned to Group 1 and 1357 children with enuresis to Group 2. Complete urinalysis results of all children who had been identified were scanned and values of urine $\mathrm{pH}$ and density were obtained. The data was evaluated for normality by frequency analysis using skewness and kurtosis. Then, differences between the two groups with regard to independent parameters (age, urine $\mathrm{pH}$, density) were statistically analyzed using the Student's t-test. A $p$ value of $<0.05$ was considered statistically significant.

\section{RESULTS}

Respective mean ages $(9.89 \pm 3.02,9.29 \pm 2.79$, and $9.87 \pm 2.99$ years); urine $\mathrm{pH}(6.28 \pm 0.57,6.22 \pm 0.62$, and 6.27 \pm 0.59 ); and urine densityvalues $(1022.75 \pm 8.9$, 1019.91 \pm 7.28 , and 1021.97 \pm 8.8 ) of Groups 1,2, and all children were as indicated. The enuretic group was younger $(p<0.001)$, and had statistically significantly lower urine $\mathrm{pH} \quad(\mathrm{p}<0.001)$, and density $(p<0.001)$ (Table 1).

Table 1. Sex, age, urine $\mathrm{pH}$, urine density values and statistical outcomes for patients in all groups.

\begin{tabular}{|c|c|c|c|c|}
\hline & $\begin{array}{c}\text { Group } 1 \\
(n=44201)\end{array}$ & $\begin{array}{c}\text { Group } 2 \\
(n=1357)\end{array}$ & $\begin{array}{c}\text { Total } \\
(n=45558)\end{array}$ & $\underset{\text { value* }}{\mathbf{p}}$ \\
\hline Sex Female $(n)$ & 23441 & 552 & 23993 & \\
\hline Male (n) & 20760 & 805 & 21565 & \\
\hline $\begin{array}{l}\text { Age (years) } \\
\text { (mean. } \pm S D)\end{array}$ & $9.89 \pm 3.02$ & $9.29 \pm 2.79$ & $9.87 \pm 2.99$ & $<0.001$ \\
\hline Urine $\mathrm{pH}$ (mean. $\pm \mathrm{SD}$ ) & $6.28 \pm 0.57$ & $6.22 \pm 0.62$ & $6.27 \pm 0.59$ & $<0.001$ \\
\hline $\begin{array}{l}\text { Urine Density } \\
\text { (mean. } \pm S D)\end{array}$ & $1022.75 \pm 8.9$ & $1019.91 \pm 7.28$ & $1021.97 \pm 8.8$ & $<0.001$ \\
\hline
\end{tabular}

SD: standart deviation, *: Student's $t$ Test, $n=$ number of children.

\section{DISCUSSION}

Enuresis is not only a urological problem but at the 
same time an important psychological problem. Both the children and their parents experience a high amount of stress throughout the process ${ }^{(4)}$. The child is subjected to shouting, condemning, and even physical punishment by the parents, whereas the parents are physically strained. If the physician fails to recognize the stressful situation surrounding the parents and the child and does not provide them with appropriate psychological/pedagogical support during this process, the likelihood of a successful medical treatment decreases. Although many studies have been done to uncover its etiology, the definitive etiology is still not known; genetics, waking problems, retarded maturation, stress, poor toilet training, defects in smooth muscle physiology, being male, and certain organic causes are among the very comprehensive list of implicated factors ${ }^{(10)}$. The most commonly implicated pathophysiological cause is low night-time Anti Diuretic Hormone (ADH) release or a decrease in retained water due to inadequate response to ADH by aquaporin receptors ${ }^{(15)}$. The prevalence of enuresis also demonstrates variability across countries. Across the world, Italy presents the lowest enuresis prevalence (3.8\%), while Australia ranks first $(18.9 \%)^{(16)}$. Studies done in our country determined this rate as $11.1 \%^{(17,18)}$. This variability in prevalence rates suggests that sociocultural status and economic parameters are among its etiologic factors. Moreover, many studies have revealed that prevalence of enuresis increases with lower levels of parental education ${ }^{(19,20)}$.

Amare et al. (21) aimed to uncover the etiology of enuresis in a study on a total of 1520 children aged between 5-18 years which included 130 children with primary enuresis (PE) and 1390 cases without $P E$. They evaluated the two groups with regard to the effects of various parameters including sex, paternal, and maternal education levels and determined the factors associated with enuresis as young age, not being the first child, deep sleep, snoring in sleep, sleeping more than two hours in the daytime, low paternal education level, the child not having received quality training, sharing the bedroom with others or siblings, and behavioral problems.

Many studies in the literature have focused on the relationship between urinary tract infections and enuresis. Recurrent urinary tract infections are thought to be involved in the etiology of voiding dysfunction and enuresis by causing changes in the bladder wall (16). Only a few publications have studied the relationship between complete urinalysis, which is the primary laboratory test requested for urinary tract infections, and enuresis. Although many studies have particularly investigated the relationship between calciuria and enuresis, we were not able to find any studies that have directly investigated the relationship of parameters such as urine $\mathrm{pH}$ and density with enuresis. In a study that included 204 children, Kozerska et al. ${ }^{(13)}$ investigated the relationship between monosymptomatic enuresis (MNE) and urinary calcium excretion, and determined higher urinary $\mathrm{Ca}^{+2}$ levels in children with MNE compared to the controls in terms of both spot and 24-hour urine. The same study did not determine any differences in urine $\mathrm{pH}$ values, and found that urine osmolality was higher in the enuresis group than in the control group. Although the study by Kozerska et al. ${ }^{(13)}$ did investigate urine $\mathrm{pH}$ and osmolality with regard to enuresis, the number of patients was quite low and a higher osmolality in the enuresis group was actually not an expected result. We think that the low number of patients could have restricted the authors' ability to arrive at accurate conclusions. Considering that our study included 45558 patients and 1357 enuretic cases, it would not be wrong to state that it is the first study that has truly revealed this relationship.

As expected, the results of our study determined that children in the enuresis group were statistically significantly younger. The lower urine density detected in the enuresis group once again suggests that $A D H$, which has been stressed in etiology, is inadequate or ineffective. ADH is a hormone that concen- 
trates the urine and its inadequacy is expected to dilute urine. A lower $\mathrm{pH}$ value suggests that there could actually be organic causes underlying enuresis. It is likely that children with enuresis have received insufficient toilet training and therefore cannot void urine effectively. Therefore, UTIs are more prevalent across children with enuresis and urine $\mathrm{pH}$ levels are accordingly lower.

\section{CONCLUSIONS}

The results of our study are consistent with current data. Our study, which will be among one of the largest-scale enuresis studies in the literature, provides guidance to physicians by reminding them the importance of urinary tract infections in the etiology of enuresis.

Author's contributions: IA, EK, UM conceived and designed research. IA, EK, EU, and YEA conducted experiments. IA, EK, YEA, MZK contributed new reagents or analytical tools. EK, EU, YEA and MZK analyzed data. IA and HM wrote the manuscript. All authors read and approved the manuscript.

Ethics Committee Approval: T.C. Bezmialem Vakıf University Rectorate Non-Interventional Research Ethics Committee approval was obtained (19.02.201904/66).

Conflict of Interest: The authors certify that there is no conflict of interest with any financial organization regarding the material discussed in the manuscript.

Funding: None.

Informed Consent: Receipt.

\section{REFERENCES}

1. Austin PF, Bauer SB, Bower W, et al. The standardization of terminology of lower urinary tract function in children and adolescents: update report from the Standardization Committee of the International Children's Continence Society. The Journal of urology. 2014;191:1863-5. e1813. [CrossRef]

2. Franco I, Von Gontard A, De Gennaro M, Society motICsC. Evaluation and treatment of nonmonosymptomatic nocturnal enuresis: a standardization document from the International Children's Continence Society. Journal of pedi- atric urology. 2013;9:234-43. [CrossRef]

3. Association AP. Diagnostic and statistical manual of mental disorders (DSM-5 ${ }^{\circledR}$ ): American Psychiatric Pub; 2013.

4. Dossche L, Walle JV, Van Herzeele C. The pathophysiology of monosymptomatic nocturnal enuresis with special emphasis on the circadian rhythm of renal physiology. European journal of pediatrics. 2016;175:747-54. [CrossRef]

5. von Gontard A. The impact of DSM-5 and guidelines for assessment and treatment of elimination disorders. European child \& adolescent psychiatry. 2013;22:61-7. [CrossRef]

6. Dolgun G, Savaser S, Balci S, Yazici S. Prevalence of nocturnal enuresis and related factors in children aged 5-13 in istanbul. Iranian journal of pediatrics. 2012;22:205.

7. Gunes A, Gunes G, Acik Y, Akilli A. The epidemiology and factors associated with nocturnal enuresis among boarding and daytime school children in southeast of Turkey: a cross sectional study. BMC public health. 2009;9:357. [CrossRef]

8. Haid B, Tekgül S. Primary and secondary enuresis: pathophysiology, diagnosis, and treatment. European urology focus. 2017;3:198-206. [CrossRef]

9. Jain S, Bhatt GC. Advances in the management of primary monosymptomatic nocturnal enuresis in children. Paediatrics and international child health. 2016;36:7-14. [CrossRef]

10. Ozden C, Ozdal OL, Altinova S, Oguzulgen I, Urgancioglu G, Memis A. Prevalence and associated factors of enuresis in Turkish children. International braz j urol. 2007;33:216-22. [CrossRef]

11. Shreeram S, He J-P, Kalaydjian A, Brothers S, Merikangas KR. Prevalence of enuresis and its association with attentiondeficit/hyperactivity disorder among US children: results from a nationally representative study. Journal of the American Academy of Child \& Adolescent Psychiatry. 2009;48:35-41. [CrossRef]

12. Kamperis K, Hagstroem S, Rittig S, Djurhuus JC. Urinary calcium excretion in healthy children and children with primary monosymptomatic nocturnal enuresis. The Journal of Urology. 2006;176:770-3. [CrossRef]

13. Korzeniecka-Kozerska A, Porowski T, Wasilewska A, Stefanowicz M. Urinary calcium excretion in children with monosymptomatic enuresis. Irish Journal of Medical Science (1971-). 2015;184:899-905. [CrossRef]

14. Sarıcı SÜ, Kısmet E, Türkbay T, et al. Bone mineral density in children with nocturnal enuresis. International urology and Nephrology. 2003;35:381-5. [CrossRef]

15. Rittig S, Knudsen UB, Norgaard J, Pedersen EB, Djurhuus JC. Abnormal diurnal rhythm of plasma vasopressin and urinary output in patients with enuresis. American Journal of Physiology-Renal Physiology. 1989;256:F664-F671. [CrossRef]

16. Wright AJ. Childhood enuresis. Paediatrics and Child Health. 2016;26:353-359. [CrossRef]

17. Oge O, Kocak I, Gemalmaz H. Enuresis: point prevalence and associated factors among Turkish children. The Turkish journal of pediatrics. 2001;43:38-43.

18. Serel TA, Akhan G, Koyuncuoğlu HR, et al. Epidemiology of enuresis in Turkish children. Scandinavian journal of urology and nephrology. 1997;31:537-539. [CrossRef]

19. Azhir A, Frajzadegan Z, Adibi A, Hedayatpoor B, Fazel A, Divband A. An epidemiological study of enuresis among primary school children in Isfahan, Iran. Saudi medical journal. 2006;27:1572-7.

20. Gürnüš B, Vurgun N, Lekili $M$, Işcan A, Müezzinoğlu T, Büyüksu C. Prevalence of nocturnal enuresis and accompanying factors in children aged 7-11 years in Turkey. Acta paediatrica. 1999;88:1369-72. [CrossRef]

21. Amare T, Zewde F. Associated Factors of Primary Enuresis Among Children and Adolescents in Amhara Region, Northwest, Ethiopia, 2016. Journal of Pediatric Nephrology. 2018;6. 